\title{
Effects of Precedent Infection of Entomopathogenic Nematodes (Steinernematidae) on the Subsequent Invasion of Infective Juveniles
}

\author{
Xiao Dong WAng ${ }^{1}$ and Nobuyoshi IsHIBASHI ${ }^{1}$
}

\begin{abstract}
Effects of precedent infection of Steinernema carpocapsae and S. glaseri on subsequent nematode invasion were investigated at $25^{\circ} \mathrm{C}$. Behavior of Galleria mellonella larvae infected through injection with ca. 50 S. carpocapsae infective juveniles did not change $6 \mathrm{hr}$ post-infection, but invasion of both nematode species decreased by ca. 50\%, compared to previously uninfected hosts. Precedent infection with $S$. glaseri promptly suppressed subsequent invasion of the two nematode species. Subsequent invasion was also significantly decreased by symbiotic Xenorhabdus bacteria: invasion rates to insects killed by $X$. nematophilus injection, $X$. poinarii injection, and by hot water treatments were $1.8,0$, and $5.4 \%$ for $S$. carpocapsae and 1.8, 5.0 and $7.8 \%$ for $S$. glaseri, respectively, while invasion rates to the non-treated live insects were $16.5 \%$ for $S$. carpocapsae and $15.1 \%$ for S. glaseri. At the early stage of the subsequent invasion, the sex ratio (\% male) of the invading $S$. carpocapsae in the hosts with and without the precedent infections were $5.3 \%$ and $12.3 \%$, respectively. These results indicated that insects infected with a Steinernema/Xenorhabdus complex may emanate suppressive substance(s) against subsequent nematode invaders. Jpn. J. Nematol. 28(1/2): 8-16 (1998).
\end{abstract}

Key words: entomopathogenic nematode, initial infection, Steinernema carpocapsae, Steinernema glaseri, subsequent invasion, suppressive substance.

\section{INTRODUCTION}

Entomopathogenic nematodes in the families Steinernematidae and Heterorhabditidae have great potential as biological control agents of many important insect pests (20). Of all developmental stages of the nematodes, only the 3rd-stage infective juveniles (IJs) can survive outside the hosts and carry their symbiotic bacteria (Xenorhabdus spp. for steinernematids and Photorhabdus spp. for heterorhabdtids) into their hosts (1). Host penetration usually occurs through natural openings (mouth, anus, spiracles, etc.) and, in some cases, directly through an intersegmental membrane (18). Once inside the host haemocoel, the bacteria are released, and they rapidly proliferate and eventually kill the hosts by causing septicemia, usually with a few days after nematode infection. In the host body, the nematodes feed on the bacteria and decayed host

${ }^{1}$ Department of Applied Biological Sciences, Saga University, Saga 840-8502, Japan.

All correspondence should be addressed to Prof. N. IsHiBASHI.

E-mail address: isibasn@cc.saga-u.ac.jp 
tissues. After two or three generations in the hosts, the IJs emerge from the insect cadavers. Penetration is critically important for nematode growth and reproduction.

So far, many studies have been conducted on nematode invasion, however, most of them focused on a low invasion efficiency, because only a small portion of the applied IJs exhibited insecticidal activiy, and the remaining majority became quiescent and/or inactive in soil environments $(2,6,7,8,11,12)$. These facts lead to a decreased efficacy of applied IJs and an increased cost of insect pest management by using nematodes.

Previous studies $(13,14,17,22)$ showed that a large portion of Steinernema carpocapsae IJs entered into a quiescent and/or noninfective state after emergence from host cadavers. The rates of noninfective IJs increased as emergence was prolonged. These facts imply a staggered nematode infection period, which may be advantageous for their species maintenance.

On the other hand, entomopathogenic nematodes seem to posses certain strategies to avoid overcrowding which would reduce adult size and fecundity, and decrease IJ production (22). Previous observations showed the infectivity of active IJs as different even in the presence of insect hosts. The present study was undertaken to see whether or not the precedent infection of $S$. carpocapsae and $S$. glaseri and of their symbiotic bacteria affects subsequent invasion by the same and different species of steinernematid nematodes.

\section{MATERIALS AND METHODS}

Nematodes: Steinernema carpocapsae strain All and Steinernema glaseri \# 328, provided from SDS Biotech Co. Ltd., were propagated at $25^{\circ} \mathrm{C}$ on Galleria mellonella larvae (5). The IJs of these nematodes were harvested daily during the period of 4 days after the first IJ emergence from insect cadavers. All harvested IJs were placed on a nylon sieve $(30-\mu \mathrm{m}$ aperture) for $2 \mathrm{hr}$ and active IJs swimming out through the sieve were used for all experiments.

Insects: The greater wax moth, G. mellonella, was reared on bee hives at $25^{\circ} \mathrm{C}$, and the lastinstars weighing about $100 \mathrm{mg}$ were used as host insects.

Effects of precedent infection on the subsequent invasion: The G. mellonella larvae were injected with either S. carpocapsae or S. glaseri, following the method described by GLAZER (1991). Briefly, IJs were surface-sterilized with merthiolate $(0.1 \% \mathrm{w} / \mathrm{v})$, rinsed three times in sterile saline, and ca. $50 \mathrm{IJ}$ in $25 \mu \mathrm{l}$ saline were injected into the insect haemocoel using a $1 \mathrm{ml}$ sterile syringe. At $0,3,6$, and $9 \mathrm{hr}$ after injection, the insects were exposed to ca. $100 \mathrm{IJs}$ of either species of the nematodes in a petri dish $(5.5-\mathrm{cm}-\mathrm{d})$ with moist filter paper. After $48 \mathrm{hr}$ exposure, the insects were dissected to record the number of nematodes in the host. The insects, injected and not injected with the sterile phosphate buffer saline, were used as controls.

The effects of precedent infection on subsequent invasion were examined using S. carpocapsae (Sc) and S. glaseri ( $\mathrm{Sg}$ ) in the following four combinations: $\mathrm{Sc}-\mathrm{Sg}, \mathrm{Sc}-\mathrm{Sc}, \mathrm{Sg}-\mathrm{Sc}$, and $\mathrm{Sg}-\mathrm{Sg}$. Each combination was performed three times with ten replicates.

Response of S. carpocapsae to non-infected and infected hosts: The precedent infection was attained by the one-on-one exposure method (19): in each well of a 24-well tissue culture plate, one IJ was pipetted and then added with one G. mellonella larva. Insects killed by nematode infection within $48 \mathrm{hr}$ at $25^{\circ} \mathrm{C}$ were used as infected hosts. Infected and non-infected hosts were individually confined in a fine wire case $(3.0 \times 0.8 \times 0.8 \mathrm{~cm})$ and placed on a semi-circle area of a $2 \%$ agar plate in a transparent rectangular plastic plate $(14 \times 10 \times 15 \mathrm{~cm})$. Two hours after the 
insect placement, ca. $100 \mathrm{IJ}$ s were inoculated on the opposite side of the agar plate, $6 \mathrm{~cm}$ away from the host. The plate was incubated at $25^{\circ} \mathrm{C}$ in an insulated box. After $6 \mathrm{hr}$, the number of IJs which stayed within $1 \mathrm{~cm}$ of the inoculation point, migrated to within $1 \mathrm{~cm}$ circle area around the host, and kept wandering in the other area were counted. Hosts were then transferred into new petri dishes, incubated for an additional $48 \mathrm{hr}$, and dissected to count invading nematodes. Based on morphological characteristics, nematodes were sexed and their sex ratio (\% male) was calculated. This experiment was performed three times with five replicates.

Nematode invasion to host insects killed by symbiotic bacteria and by hot water: Ten $S$. carpocapsae or S. glaseri were injected into the abdomen of G. mellonella larva. After $24 \mathrm{hr}$, the insect prolegs were cut to bleed and the haemolymph was streaked on 100-mm LB plates (Bacto tryptone $10 \mathrm{~g}$, Bacto yeast extract $5 \mathrm{~g}, \mathrm{NaCl} 10 \mathrm{~g}$, agar $15 \mathrm{~g}$, deionized water 1,000 $\mathrm{ml}$ ) using a glass rod (24), and incubated at $25^{\circ} \mathrm{C}$ for 3 days. The characteristic colonies of Xenorhabdus nematophilus and of Xenorhabdus poinarii developed on the plates were subcultured until a pure culture was obtained. These pure bacterial cultures were transferred to nutrient broth slants, incubated at $25^{\circ} \mathrm{C}$ for 3 days, and stored at $6^{\circ} \mathrm{C}$. The purified bacteria were subcultured at least once a month to maintain viability (23).

Thirty to $40 \mu \mathrm{l}$ of a suspension containing 60,000 bacterial cells $/ \mathrm{ml}$ sterile saline, was injected into $G$. mellonella larvae. Insects killed in $24 \mathrm{hr}$ by injection with $X$. nematophilus, with $X$. poinarii, by hot water, and non-treated alive ones were individually placed in fine wire cases. The cases containing insects after four treatments were placed equal distant from each other on the periphery of a $2 \%$ agar plate $(5-\mathrm{cm}-\mathrm{d})$. Fifty IJs of S. carpocapsae or S. glaseri were inoculated on the plate center. Twenty-four hr after inoculation, the insects were removed, rinsed and transferred to new petri dishes. After an additional $48 \mathrm{hr}$ incubation, the insects were dissected to count invading nematodes. This experiment was performed three times with five replicates.

Nematode penetration to BT-infected hosts: G. mellonella larvae were allowed to feed on bee hives which were surface-coated with a suspension of Bacillus thuringiensis (BT) provided from SDS Biotech Co. Ltd. ( $1 \mathrm{~g}$ powder of BT/2,000 $\mathrm{ml}$ distilled water). On 0, 24, and $48 \mathrm{hr}$ postfeeding, the insects were individually exposed to ca. 100 IJs of S. carpocapsae on a petri dish (5$\mathrm{cm}-\mathrm{d})$. After additional $48 \mathrm{hr}$ incubation, the insect cadavers were dissected to record the invading nematodes. Insects not exposed to BT were used as controls. This experiment was performed three times with ten replicates.

Data analysis: Unless otherwise indicated, data were subjected to ANOVA (analysis of variance) at the 0.01 level of significance. Means were separated with TUKEY's studentized range test at the 0.05 level of significance. Nematode response to non-infected and infected host, male ratio, penetration rates to the hosts killed by the symbiotic bacteria and by the hot water treatments were compared using $t$-test at the 0.01 level of significance. Date are presented as means \pm standard error.

\section{RESULT}

Effects of precedent infection on the subsequent invasion: Figure 1 shows invasion rates of $S$. carpocapsae and S. glaseri to G. mellonella larvae which were pre-infected by the infection of 50 IJs of either nematode species.

When insects were pre-infected with $S$. carpocapsae, subsequent invasion by the two nematode 

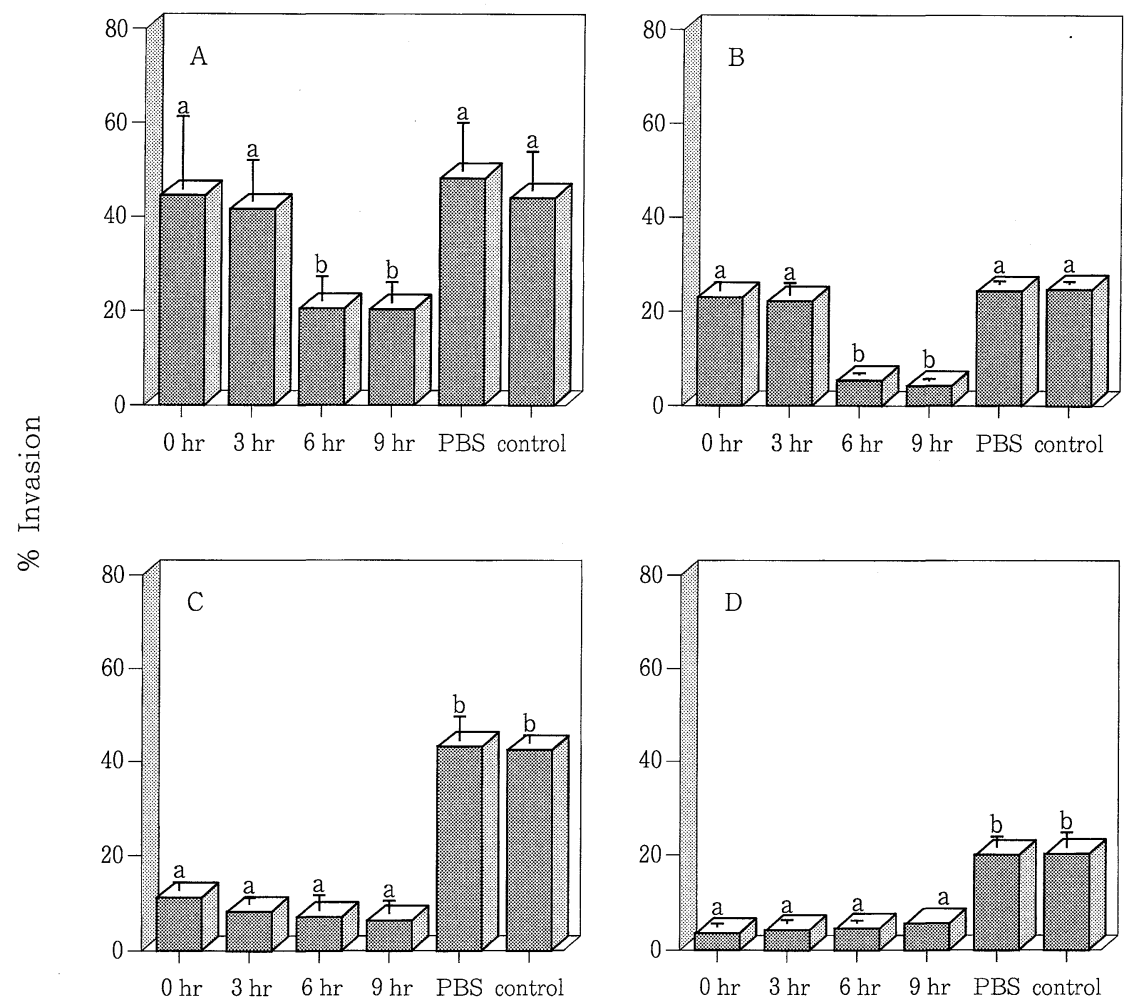

Hours after injection

Fig. 1. Invasion of S. carpocapsae (Sc) and S. glaseri (Sg) to G. mellonella larvae injected and not injected with ca. 50 infective juveniles into the insect haemocoel. On 0, 3, 6, and $9 \mathrm{hr}$ after the injection, the insects were exposed for $48 \mathrm{hr}$ to ca. 100 infective juveniles (IJs) in a petri dish. The insects inoculated with and without a phosphate buffer saline (PBS) were served as controls.

A : exposure to Sc after Sc injection

B : exposure to $\mathrm{Sg}$ after Sc injection

$\mathrm{C}$ : exposure to $\mathrm{Sc}$ after $\mathrm{Sg}$ injection

D : exposure to $\mathrm{Sg}$ after $\mathrm{Sg}$ injection

species decreased through time. Namely, the invasion rates were decreased significantly from 6 hr post-infection: 45.4, 42.6, 21.2, and 20.8\% for S. carpocapsae (Fig. 1A) and were 23.2, 22.5, 5.2, and $3.9 \%$ for S. glaseri (Fig. 1B) after the insect exposure to ca. $100 \mathrm{IJs}$ for $0,3,6$, and $9 \mathrm{hr}$, respectively.

Conversely, pre-infection with S. glaseri drastically decreased subsequent invasion rates of S. glaseri and S. carpocapsae immediately after the pre-infection. Actually, the invasion rates at the post-exposure time noted above were 11.0, 8.0, 6.6, and 6.0\% for S. carpocapsae (Fig. 1C), and $3.8,4.4,4.6$, and $5.8 \%$ for S. glaseri (Fig. 1D), respectively. All of these values were significantly lower than those for the insects injected with the phosphate buffer saline or the non-inoculated ones used as controls.

Migration of S. carpocapsae to non-infected and infected hosts: Table 1 shows the ratios of S. carpocapsae IJs 1) stayed in the inoculation site area, 2) attracted to the host insect area, and 3) actively kept wandering in other areas of the plate. The IJs were more attracted to the non- 
Table 1. Response of S. carpocapsase infective juveniles to Galleria mellonella larvae infected and non-infected with the nematodes.

\begin{tabular}{lccc}
\hline \multirow{2}{*}{ Insects used } & \multicolumn{3}{c}{$\%$ nematodes in the area of } \\
\cline { 2 - 4 } & inoculation site & host insect & others \\
\hline non-infected & $42.3 \pm 6.2 \mathrm{a}$ & $17.6 \pm 1.5 \mathrm{a}$ & $40.1 \pm 3.1 \mathrm{a}$ \\
infected & $69.0 \pm 13.3 \mathrm{~b}$ & $8.2 \pm 1.3 \mathrm{~b}$ & $22.8 \pm 5.9 \mathrm{~b}$ \\
\hline
\end{tabular}

* The response was examined $6 \mathrm{hr}$ after nematode placement on the central area of $2 \%$ agar plate in transparent quadrant plastic plates $(14 \times 10 \times 1.5 \mathrm{~cm})$.

* * Values in the same column followed by the same letter are not significantly different $(\mathrm{p}>0.01)$ according to a $t$-test.
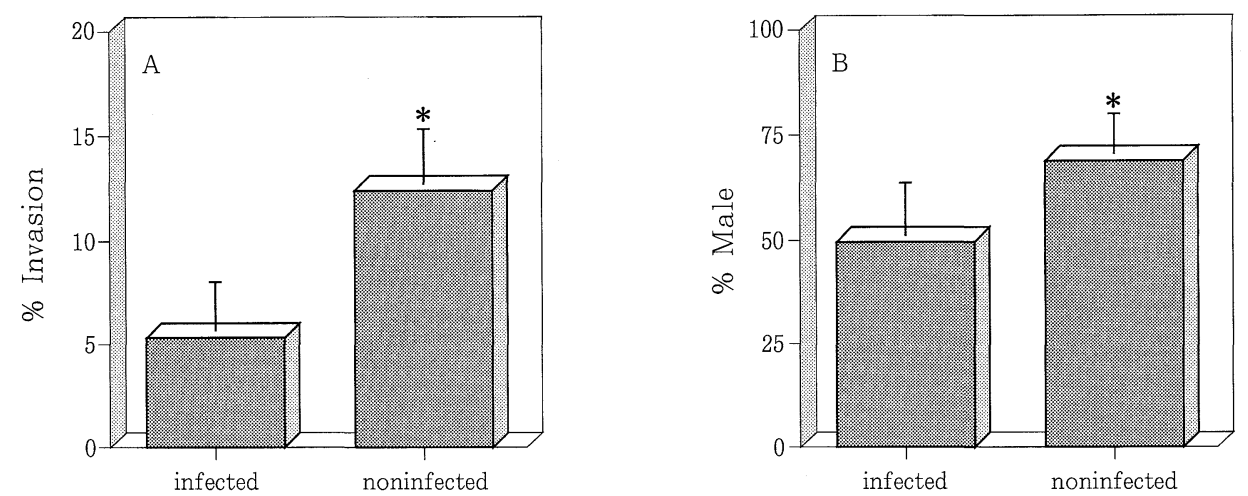

Host infection status

Fig. 2. Invasion rates (A) and male ratios (B) of S. carpocapsae in G. mellonella larvae pre-infected and non-infected by the infection with 50 infective juveniles. The data were obtained $6 \mathrm{hr}$ post-infection. Vertical lines indicate standard error and those with asterisks are signficantly different $(t$-test, $\mathrm{p}<$ $0.01)$.

infected hosts than to the pre-infected ones: the ratios of IJs falling into the above three areas were $42.3,17.6$, and $40.1 \%$ for the non-infected hosts, and $69.0,8.2$, and $22.8 \%$ for the pre-infected ones, respectively. These differences were significant. Consequently, nematode penetration rates were significantly higher to the non-infected hosts (12.3\%) than to pre-infected ones (5.3\%) (Fig. $2 \mathrm{~A}$ ). The sex ratios (\% male) of all invading nematodes were also significantly higher in noninfected hosts than in the pre-infected ones (Fig. 2B).

Nematode penetration to the hosts killed by Xenorhabdus bacteria and by hot water: Penetration rates of $S$. carpocapsae and $S$. glaseri were significantly lower in the insects killed by the symbiotic bacteria or by the hot water treatment than in the non-treated, live controls (Fig. 3). When the comparison was made between the insects killed by the becteria and by the hot water, the decrease in the penetration rates of the two nematode species were more significant for the former than the latter treatment. In addition, subsequent penetration of the two nematode species was less significantly suppressed by injection of their own symbiotic bacteria than those of the other nematode species. In the case of S. glaseri, the penetration rate to insects killed by $X$. poinarii and by $X$. nematophilus were 5.0 and $1.8 \%$, respectively. Conversely, penetration of $S$. 
carpocapsae was completely suppressed by the injection of $X$. poinari, although $1.8 \%$ penetration was obtained when injected with $X$. nematophilus, the symbiont of $S$. carpocapsae.

Nematode penetration to BT-treated hosts: The penetration of S. carpocapsae to G. mellonella larvae was not affected by allowing the insects to feed on BT-treated diet for up to $48 \mathrm{hr}$ before nematode inoculation (Fig. 4). There were no statistical differences between treatments with different feeding periods.

\section{DISCUSSION}

Previous studies $(17,22)$ reported a strategy of Steinernema carpocapsae which circumvents local extinction by having active and inactive host seeking periods. In the present investigation, we demonstrated other species maintenance strategies in steinernematid nematode.

One of the demonstrated strategy is a suppression of nematode invasion by precedent infection with steinernematids. Namely, the invasion rates of S. carpocapsae to G. mellonella larvae significantly decreased from $6 \mathrm{hr}$ after pre-infection with either S. carpocapsae or S. glaseri. This result was similar to GLAZER's result (9). Conversely, pre-infection with S. glaseri drastically reduced subsequent invasion of both nematode species; immediately after pre-infec-



Fig. 3. Invasion rates of S. carpocapsae (A) and $S$. glaseri (B) to G. mellonella larvae with no treatments (control), injected with $X$. nematophilus, injected with $X$. poinarii, and treated with hot water. Vertical lines indicate standard error and those with one and two asterisks are different at $p<0.05$ and $p<0.01$, respectively ( $t$-test). tion. The different effects of pre-infection on subsequent invasion of the two nematode species may be due partly to the different times required for proliferation of the symbiotic bacteria of the respective nematode species $(3,4)$. These results are likely caused by an unknown substance(s) which accumulate(s) in the hosts to suppress subsequent nematode invasion. In addition, different subsequent invasion may be

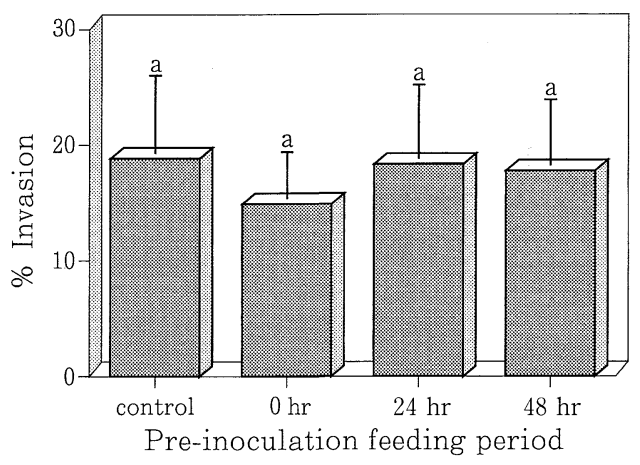

Fig. 4. Invasion rates of $S$. carpocapsae to $G$. mellonella larvae. The insects were inoculated with ca. 100 infective juveniles after being allowed to feed on the nontreated diet (control) and on the Bacillus thuringiensis-treated diet for 0, 24, and 48 hr. Vertical lines indicate standard error. 
related to the host foraging behavior; S. glaseri could more strongly respond to the chemical substance(s) from a distance than $S$. carpocapsae.

On an agar plate, we observed the attraction of infective juveniles to their own symbiotic bacteria (unpublished). However, in the present experiment, invasion rates of these two nematode species were noticeably lower to the insects killed by injection of symbiotic bacteria than to those killed by hot water treatment. This may also indicate a contribution of the symbiotic bacteria to the reduction of subsequent nematode invasion. Under natural conditions, reduced nematode invasion caused by the nematode-bacteria complex could be one of the survival strategies of steinernematid nematodes. Namely, it will avoid overcrowding which may lead to a lowered fecundity of females and fewer infective juveniles (21).

In the field, only a small portion of IJs are infective at the time of application. This attribute may be heritable and may serve to guard against local extinction. However, these characters will not always make nematode application successful for insect pest control. One possible solution may be the use of chemicals which keep IJ mobility and/or infectivity high even at low temperatures (16). Mixed applications of nematodes and insecticides has provided effective control of insect pests in field trials $(10,15,16)$. The reason is not fully understood yet, but such mixed applications make the steinernematid nematodes work better under field condition.

\section{ACKNOWLEDGMENTS}

We thank Dr. S. YAMANAKA, SDS Biotch Co. Ltd. for offering steinernematid nematodes and Bacillus thuringiensis. Cordial thanks are also due to Dr. E. Kondo, Saga University, for criticism.

\section{LITERATURE CITED}

1) Akhurst, R. J. (1993) Neoaplectana species: specificity of association with bacteria of the genus Xenorhabdus. Int. J. Syst. Bacterial. 33, 38-45.

2 ) CARoli, L., Glazer, I. \& Gaugler, R. (1996) Entomopathogenic nematode infectivity assay: multivariable comparison of penetration into different hosts. Biocon. Sci. Tech. 6, 235-245.

3 ) Dunpy, G. B. \& Webster, J. M. (1984) Interaction of Xenorhabdus nematophilus subsp. nematophilus with the haemolymph of Galleria mellonella. J. Insect Physiol. 30, 883-889.

4 ) Dunpy, G. B. \& Thurston, G. S. (1990) Insect immunity. In: Entomopathogenic Nematodes in Biological Control (Gaugler, R. \& Kaya, H. K., eds.), CRC Press, Boca Raton, FL, 365 pp.

5 ) Dutky, S. R., Thompson, J. V. \& Cantwell, G. E. (1964) A technique for the mass propagation of the DD-136 nematode. J. Insect Pathol. 6, 417-422.

6) FAn, X. \& Hominick, W. M. (1991a) Efficacy of Galleria mellonella (wax moth) baiting technique for recovering infective stages of entomopathogenic rhabditids (Steinernematidae and Heterorhabditidae) from sand and soil. Rev. Nematol. 14, 381-387.

7 ) FAn, X. \& Hominick, W. M. (1991b) Effects of low storage temperature on survival and infectivity of two Steinernema species (Nematoda: Steinernematidae). Rev. Nematol. 14, 407-412.

8 ) Glazer, I. (1991) Invasion rate as a measure of infectivity of steinernematid and heterorhabditid nematodes to insects. J. Invertebr. Pathol. 59, 90-94.

9 ) Glazer, I. (1997) Effects of infected insects on secondary invasion of steinernematid entomopathogenic nematodes. Parasitology 114, 597-604.

10) Hatsukade, M., Kataya, H. \& Yamanaka, S. (1998) Pathogenicity of the entomogenous nematode, Steinernema sp., to scarabaeid larvae injurious to turfgrass. J. Jpn. Soc. Turfgrass Sci. 17, 53-58. 
11) HAy, D. B. \& FEnlon, T. S. (1995) A modified binomial model that describes the infection dynamics of the entomopathogenic nematode Steinernema feltice (Steinernematidae; Nematoda). Parasitology 111, 627-633.

12) Hominick, W. M. \& ReID, A. P. (1990) Perspectives on entomopathogenic nematology. In: Entomopathogenic Nematodes in Biological Control (GAugler, R. \& KaYA, H. K., eds.), CRC Press, Boca Raton, FL, 365 pp.

13) Ishibashi, N. \& Kondo, E. (1986) A possible quiescence of the applied entomogenous nematode, Steinernema feltiae, in soil. Jpn. J. Nematol. 16, 66-67.

14) Ishibashi, N. \& Kondo, E. (1990) Behavior of infective juveniles. In: Entomopathogenic Nematodes in Biological Control (Gaugler, R. \& Kaya, H. K., eds.), CRC Press, Boca Raton, FL, 139 pp.

15) Ishibashi, N. \& Chol, D. R. (1991) Biological control of soil pests by mixed application of entomopathogenic and fungivorous nematodes. J. Nematol. 23, 175-181.

16) Ishibashi, N. \& TAKII, S. (1993) Effects of insecticides on movement, nictation, and infectivity of Steinernema carpocapsae. J. Nematol. 25, 204-213.

17) Ishibashi, N., Wang, X. D. \& Kondo, E. (1994) Steinernema carpocapsae: poststorage infectivity and sex ratio of invading infective juveniles. Jpn. J. Nematol. 24, 60-68.

18) Kondo, E. \& Ishibashi, N. (1989) Non-oral infection of Steinernema feltiae (DD-136) to the common cutworm, Spodoptera litura (Lepidoptera: Noctuidae). Appl. Entomol. Zool. 24, 85-95.

19) Miller, R. W. (1989) Novel pathogenicity assessment technique for Steinernema and Heterorhabditis entomopathogenic nematodes. J. Nematol. 21, 574.

20) Poinar, G. O., Jr. (1990) Taxonomy and biology of Steinernematidae and Heterorhabditidae. In: Entomopathogenic Nematodes in Biological Control (GAUGLER, R. \& KAYA, H. K., eds.), CRC Press, Boca Raton, 365 pp.

21) Selvan, S., Campbell, J. F. \& Gaugler, R. (1993) Density-dependent effects on entomopathogenic nematodes (Heterorhabditidae and Steinernematidae) within an insect host. J. Invertebr. Pathol. 62, 278-284.

22) Wang, X. D., Kondo, E. \& Ishibashi, N. (1997) Infectivity of entomopathogenic nematode, Steiner nema carpocapsae, as affected by the emergence time from the host cadaver. Jpn. J. Nematol. 27, $1-6$.

23) Wouts, W. M. (1981) Mass production of the entomogenous nematode Heterorhabditis heliothidis (Nematoda: Heterorhabditidae) on artificial media. J. Nematol. 13, 467-469.

24) WANG, Y. \& GAUGLeR, R. (1995) Infection of entomopathogenic nematodes Steinernema glaseri and Heterorhabditis bacteriophora against Popillia japonica (Coleoptera: Scarabaeidae) larvae. J. Invertebr. Pathol. 66, 178-184.

Accepted for publication: October, 17, 1997. 


\section{和文摘要}

\section{Steinernematidae 科昆虫病原性線虫の先行感染が その後の線虫感染に及ぼす影響}

\section{王 小冬・石橋信義}

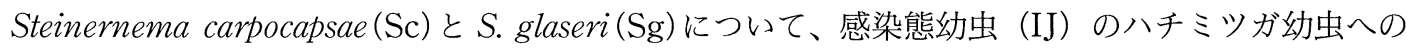

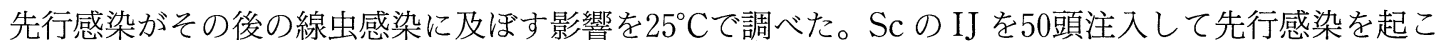
すと、感染昆虫への Sc および Sgのその後の侵入率は、非感染昆虫に比べて約 $50 \%$ 低下した。Sg を先 行感染させた場合、感染直後から、宿主昆虫への Sc および Sg の侵入率は著しく低下した。Xenorhabdus nematophilus (Scの共生細菌) 注入、X. poinarii (Sgの共生細菌) 注入および熱処理で死亡した昆 虫への侵入率は、それぞれ、Sc の場合で1.8\%、0 \%、5.4\%、Sgの場合で1.8\%、5.0\%、7.8\%とな り、共生細菌感染で死亡した昆虫への侵入率がより顕著に低下した。この時の無処理生存昆虫への侵 入率は、Sc で16.8\%、Sg で15.1\%となり、昆虫死体への侵入率より高かった $(\mathrm{p}<0.01)$ 。宿主昆虫 への侵入率は線虫の先行感染によって有意に低下し、Sc の侵入率は、未感染昆虫で $12.3 \%$ 、既感染昆 虫で $5.3 \%$ となった。感染初期 (接種後 6 時間) における侵入線虫の雄性比も同様に低下し、未感染昆 虫で $69.0 \%$ 、既感染昆虫で49.3\%であった。これらの結果より、共生細菌を有する Steinernema 属線 虫の感染で死亡した昆虫体は、その後の線虫侵入を抑制する物質を出しているものと推察された。 